Article

\title{
Does Ownership Determine Business Model?
}

\author{
Li Zhang ${ }^{1}$, Yingqi Liu ${ }^{1, *}$ and Ari Kokko ${ }^{2}$ \\ 1 College of Economics and Management, Beijing Jiaotong University, Beijing 100044, China; \\ zhangli628000@126.com \\ 2 Department of International Economics, Government, and Business, Copenhagen Business School, \\ 2000 Copenhagen, Denmark; ako.egb@cbs.dk \\ * Correspondence: liuyq@bjtu.edu.cn; Tel.: +86-1350-112-5524
}

Received: 27 April 2019; Accepted: 30 May 2019; Published: 4 June 2019

check for updates

\begin{abstract}
The development of a new energy vehicle industry is considered a sustainable approach to solving the global energy crisis and the problem of environmental pollution. The sales of new energy vehicles in China are the highest in the world, and China's new energy vehicle enterprises have played an important role in this. The business model, as a method for enterprises to achieve their strategic goals, utilizes resource advantages to deliver value to consumers, and is affected by enterprises' ownership, competitive strategy, and resources. Based on the resource-based view (RBV) theory, the article uses a mixed quantitative and qualitative methodology, selects 30 vehicle enterprises from the mainstream market, and takes product value, suppliers, dealers and external relations, research capabilities, shareholders, and profitability as potential explanatory elements to analyze business model differentiation between different ownership categories. The article explores the reasons for the differences in business models between different ownership classes through case studies and data comparisons. It examines the characteristics and types of business model based on resources and competitive strategy. This study suggests that the ownership of enterprises plays a decisive role in strategic choices and resource acquisition and has a differential impact on the business model in resources and revenue dimensions. A business model represents the result of the interaction between competitive strategy and historical resources, which in turn demonstrates that ownership determines business model.
\end{abstract}

Keywords: new energy vehicle enterprises; ownership; business model; strategy; resources

\section{Introduction}

Rapid global economic growth has led to an increasing concern for energy security and sustainable development. The transport sector accounts for about a quarter (23\%) of global energy-related greenhouse gas (GHG) emissions [1]. China's energy demand is growing rapidly. China's imports of oil have increased nearly $2 \%$ each year, and the country has overtaken the United States as the largest importer of crude oil since 2015 [2]. In addition to the energy crisis, the problem of carbon dioxide emission caused by vehicles has become more severe. According to a survey by the Intergovernmental Panel on Climate Change (IPCC), $14 \%$ of GHG emissions come from transportation. Almost $95 \%$ of petroleum fuels, mainly gasoline and diesel, are used for transportation globally [3], and the atmosphere is suffering from the increasing number of vehicles. At the end of 2016, global car ownership had reached 194 million, an increase of $113 \%$ since 2010 [4]. China ranks first in the world for carbon dioxide emissions, which are roughly $30 \%$ [5].

In order to deal with the severe challenges from the environment and energy issues, China, as the world's largest vehicle producer and consumer, began in 2009 to develop a new energy vehicle industry. By improving energy efficiency and reducing environmental pollution, the Chinese government aims to contribute to an economically sustainable development. The Chinese government has included 
the new energy vehicle industry as one of the seven emerging industries in the 12th five-year plan, to achieve a green, scientific and sustainable low-carbon economy.

Since 2001, China's central government has promulgated a number of policies to promote the development of the new energy vehicle industry. These policies cover various aspects of strategy and investment, subsidies, tax and incentives, regulations and standards, etc., and they have jointly accelerated industrial development. With the encouragement of policies and the effort of enterprises, China has become the world's largest electric vehicle market since 2015, reaching more than 100,000 units of exports in the global market [6], maintaining a continuous high-speed growth. According to the market data, total sales in 2017 reached 777,000, up 53.3\% over the same period of the previous year [7].

Despite many notable achievements, China's new energy vehicle industry still faces some challenges: high prices, short mileage, inadequate driving experience, and a weak charging infrastructure compared with traditional vehicles. In the future, with the planned cancellation of the subsidy policy for new energy vehicles in 2020, the policy-driven market is gradually disappearing. At the same time, the long-term and high-input characteristics of technology will slow down the progress of commercialization, which will bring fresh challenges for the new energy vehicle industry. As an effective means to promote commercialization, the business model plays an increasingly important role in the operation of new energy vehicles. Under the same technical conditions, exploring different business models could help to promote the market.

The business models in China's new energy vehicle industry have contributed to many practical results. According to research, China's new energy vehicle industry is divided into four stages: market germination (2001-2008), market launch (2009-2012), market acceleration (2013-2015), and market deepening (2016-present). In the first stage, new energy vehicle enterprises explored the market but did not form a competitive market. The business model is a demonstration of large-scale event projects. For example, Chery, Changan, FAW Group, BAIC Foton, Shanghai Volkswagen, Jinghua Bus and Dongfeng Motor provided 500 energy-saving and new energy vehicles for the Beijing Olympic Games. In the startup phase, new energy vehicle enterprises adopted cost leadership strategies to complete the "Ten Cities and Thousand Vehicles" demonstration project, producing at lower cost and promoting a large number of public transportation vehicles. At the end of 2012, 27,432 vehicles were produced, of which 23,032 were promoted in the public sector in 25 demonstration cities. During the acceleration stage, models such as Hangzhou Micro-Bus, Potevio Mode, and Hefei Targeted Purchase emerged. Whereas most enterprises focused on the low-end market, some enterprises that have foundations in the public sector adopted a differentiated strategy. For example, SAIC Group's EVCARD uses high-end models to improve consumer travel services. In the deepening stage, new energy vehicle technology has developed rapidly, charging infrastructure construction has gradually improved, and innovative business models have gained more support in the private purchase field. The strategy of new energy vehicle enterprises is diversified. State-owned enterprises such as Dongfeng and Changan mainly market low-cost and low-end models. Private enterprises represented by BYD use the advantages of battery technology to select mid- to high-end market routes [8].

The emergence of new business models has received much attention from the academic community. Scholars have studied the elements of business models and the bases for business model innovation. The business model links combinations of assets to value creation [9]. The ultimate success of each enterprise depends not on its ability to make the most of just one or two assets, but on its skill in optimizing all assets that make up its business model.

In fact, firms must acquire resources concomitantly to the implementation of a new business model [10]. According to the classical resource-based view (RBV) theory, firms are fundamentally heterogeneous regarding their resources and internal competencies [11]. The heterogeneous resources of a firm contribute to its strengths and weaknesses [12]. To secure sustainable competitiveness, a firm's resources must have four attributes: value, rareness, imperfect imitability, and substitutability. Firm resources can be imperfectly imitable for one, or a combination of three reasons: history-dependent, causally ambiguous, and socially complex [11]. The resource-based view theory explains that the 
firms that are acquiring and exploiting certain resources depend upon their position in time and space. Because each firm's history is unique, their resources are imperfectly imitable. In China, state-owned enterprises (SOEs) are more dependent on historical resources than other ownership enterprises. Most resources are in the hands of SOEs because externalities will affect the allocation and efficiency of resources [13].

Recently, the increasing influence of China's SOEs at home and abroad has caused heated discussions about the ownership of these enterprises. China is the second largest economy in the world, and SOEs have contributed substantially. According to Szamosszegi and Kyle's report, SOEs and state-owned holding enterprises account for more than 40\% of GDP in secondary and tertiary industries. In other important pillar industries, SOEs are still major players [14]. With the reform of China's state-owned system and the transformation of its economic structure, the business models of state-owned enterprises and other ownership categories will have a big impact on industry dynamics and competition.

Business model choices and how they evolve are usually researched from different perspectives. However, the research seldom relates to the factors that affect the heterogeneity of business models, especially in relation to China's new energy vehicle enterprises. Barquet et al. analyzed five factors influencing business model heterogeneity from the perspective of sustainability: apply design for environment, identify economic value, promote behavioral change, act towards social well-being, and innovate at different levels [15]. The present article highlights how business models differ depending on ownership of resources. We address this topic by exploring the following question: Does ownership determine the business model? Based on a qualitative analysis of 30 enterprises in China's new energy vehicle (NEV) industry, we aim to establish the main determinants of business model choices and to present an overview that integrates the main types of business model into the new energy vehicle industry.

Section 2 reviews the business model literature and analyses how resources and strategy influence it. Data and methods are presented in Section 3. Section 4 first uses quantitative analysis to show that ownership has a differential impact on business models. Then, according to visible resources and strategic positioning, we construct a classification framework of China's new energy enterprises. Heterogeneous resources and market positioning strategy appear to be key variables to split the sample of enterprises into four clusters. The differential impact of resources and strategies on business models is analyzed. Finally, the reasons for this differentiation, that is, the influence of ownership on resources and strategies, are discussed in depth. Thus the dynamic transitioning of business models are shown in the end. New challenges from ownership will also be discussed in Section 5. Section 6 presents the conclusions.

\section{Literature Review}

\subsection{What is a Business Model?}

A company's business model has been argued to be the most important factor in its success or failure in the marketplace-more so than other factors [11]. The analysis of business models as a process model first gained significance with the development of advanced technology in e-business [16]. Konczal regarded the business model as a management tool, which can be understood as an operative activity for system modelling [17]. With more strategy research, the business model has been seen not only an operative plan but also as a helpful visualization of the organization in order to support decision-making in organizational management $[18,19]$. A business model defines static characteristics as well as dynamic ones. The dynamic characteristics of the business model involve the business model design of startup enterprises and the business model innovation of incumbents [20].

From the perspective of the static definition, the business model is commonly described as strategy choice, resource accumulation and value creation. Firstly, Richardson describes a business model as "the conceptual and architectural implementation of a business strategy and as the foundation for 
the implementation of business processes" [21]. In terms of strategy execution, the business model provides an analytical framework including some critical dimensions for the company's competitive advantages [22]. Richardson proposed three dimensions: value proposition, value creation, and value capture. Value proposition concerns the offering and customer segmentation [21]. Value creation deals with resources, the value chain, structures, and processes. Value capture includes the cost structure and revenue model [23]. To some extent, the business model emphasizes a company's strategic competition and reflects on the network.

In addition, materials and resources are frequently cited as important aspects of a company in the business model literature [24,25]. Identifying and leveraging organizational assets are the most important elements in building a successful business for the new economy [26]. In aggregate, assets are the input factors of a business model [27], no matter which field. The special combination of enterprises' assets constitutes the core of a firm's business model, which ultimately increases its economic value and promotes the success of the company [25]. Based on the resource theory, each business model is considered to have its own set of development logic [28]. This set of logic is consistent with the required resources. Business models are made up of asset portfolios in which the components interact, but that does not mean traditional assets alone-physical assets and financial capital are also included. Further included are a diverse set of intangibles such as relationship, intellectual property, leadership and so on.

The value area is concerned with general structure of value creation and useful topology of partners [29]. The business model refers to the conceptual logic of how the firm creates and appropriates economic value [30]. Focused on the value capture process, this logic explains how enterprises deliver value to consumers [31].

Besides business models in general, many researches highlight innovative business models, especially sustainable business models, e.g., the circular business model (CBM). Compared to linear business models, the circular business model concerns the rationale of how an organization creates, delivers, and captures value with and within closed material loops [14]. In CBMs, business should be conducted in a sustainable manner that provides, in addition to economic gains, measurable environmental and/or social value [32,33]. The research on CBMs is actually a development and extension of industrial servitization research [26] and assumes a fixed boundary. Although resource loops are relatively closed in China's automobile industries, the new energy vehicle enterprises have sought help from global markets, breaking through China's industrial boundaries and even crossing into other industries. Therefore, this article does not refer to CBMs, and only concentrates at the level of enterprises. At this level, the business model is a conceptualization of how organizations use resources that create, deliver, and capture value for its customers or its partners, and thus realizes their strategic goals.

\subsection{Business Model Based on RBV}

The resource-based view theory is useful in analyzing an emerging industry that relies primarily on a combination of basic resources because there are few products or services and unclear market positioning at the beginning of development [34]. Garnsey et al. believe that the RBV theory is designed to link business models with resource acquisition and distribution [35]. Korsaa and Røge Jensen divide assets into five core categories: physical, financial, employee and supplier, customer, and organization [12]. This framework makes it possible to identify and classify all sources of value within these five categories.

There are several connections between the business model and RBV theory. The first school of thought suggests that a business model links a combination of assets to value creation [12]. The value of the business model improves as the bundle of resources and capabilities paralleling both conceptions to competitive advantage increase. Equally Schweizer considered the RBV theory the underlying foundation for business models, necessary to identify and develop resources and capabilities which are crucial to sustainable competitive advantage [36]. However, every company has generic resources that 
do not create competitive differentiation [37]. Business models integrate resources which highlight their capabilities and create value. The second school of thought is that a business model is a part of a resource, referring particularly to intellectual resources [38]. Like technology, the business model, as one part of the intellectual property, provides a series of activities for servicing a segmented market, so as to form an alternative competitive capability [39].

Overall, resources are the basis of sustainable development, not parallel with the evolution of business model. Meanwhile, resources are the source of capabilities [40]. Through integrating resources to harness capacity and opportunity, a business model builds an architecture to depict its core logic and maintain a competitive advantage. Thus, we propose the first hypothesis.

Hypotheses 1 (H1): Business model differentiation is determined by different resources.

\subsection{Business Model and Strategy}

Strategy and the business model, though related, are different concepts: a business model is the direct result of strategy but not the strategy itself [41]. As mentioned earlier, many scholars have studied the impact of strategy on business models [42-44]. As above, the strategic aspect defines the business model as an architectural implementation of a business strategy. The strategy is required to establish an advantage over competitors, but the business model is designed to study competitive advantages in order to bridge the gap between strategy and execution. It also provides support for value propositions and turns the advantages of strategy into sustained excess profits, thereby enhancing the company's performance.

The substantive difference between strategy and a business model arises when execution calls for modification of a business model (changes in policies and/or assets and/or governance) when particular contingencies arise. In such cases, strategy and the business model no longer coincide, regardless of whether the business model change is substantial or minor. Strategy achieves the goal through one or several business models, but the elements of the business model will be laid out around the strategic goal. Then, only one business model will be selected. The respective concepts of strategy and the business model are complementary, however, not substitutes.

When a business model is applied to industry, there is a clear difference between the strategy and the business model. The business model, as a source of value, can help explain why some firms outperform others. Strategy involves a vision, and a company's policy on the environment or competition can suggest which direction strategy will go in the future [45]. Fundamental decisions are made about medium and long-term objectives and activities of a company. Because competitors can acquire the same economic input from the region, competitive advantage in the new paradigm lies in taking control of the business model and intelligently facilitating suppliers to link up together to accommodate that model. Therefore, the difference between business model and strategy at the industry level is reflected in the competitive advantage, and the consistency between the business model and strategy will be not the same. Based on a review of the relationship between strategy and business models, this article proposes a second research hypothesis, set out below.

Hypotheses 2 (H2): The business model is driven by different strategies.

Hypotheses 1 and 2 underline the fact that enterprises target different resources and strategies through business models to ensure their sustainable development. The business model links resources and values, and gains support from different ownership constellations of enterprises. On the one hand, shareholders define the type of ownership; on the other hand, the shareholders determine the enterprise strategy. Therefore, different ownership forms different strategies, which determine the method and size of resource acquisition. This paper further explores the underlying factors that affect resource acquisition and strategic decision-making, that is, ownership. Therefore, we look for differences in resources and strategy among state-owned enterprises, private enterprises (PEs), and joint ventures (JVs). The following hypotheses are put forward. 
Hypotheses 3 (H3): Different ownership forms determine resources.

Hypotheses 4 (H4): Different ownership forms determine strategies.

The business model is based on the RBV theory, an important method of achieving strategic goals. The business model is an explicit reflection of strategy. Strategic decisions are made by shareholders and influence the displayed business model. The strategic positioning and resources can be expressed through the business model. The final hypothesis discusses the impact of enterprise ownership on business models. The ownership of the entire vehicle enterprise directly determines the nature or degree of resource acquisition and strategic choices. Based on the above literature review and hypotheses, ownership has an indirect effect on the business model. The last hypothesis is put forward, and the research framework is proposed, see Figure 1.

Hypotheses 5 (H5): Different ownership determines business models.

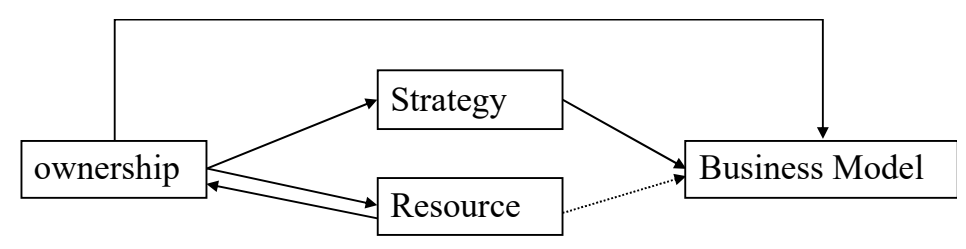

Figure 1. Research model.

\section{Materials and Methods}

\subsection{Case Selection}

According to the statistics of the Ministry of Industry and Information Technology, there were 130 passenger car manufacturers in China in 2017 [46]. There were 65 new energy vehicle enterprises on the published list of new energy vehicle credits participating in vehicle production, accounting for $50 \%$ of all passenger vehicle manufacturers in China. These enterprises include the following two categories. The first category is mainly based on traditional vehicle enterprises, opening up new energy vehicle business. For example, BYD has established the new energy vehicle business division that is responsible for researching and producing core components. The second category includes enterprises approved by the Chinese government since 2016 that have a qualification for pure electric vehicle production. These include spin-offs from traditional vehicle enterprises and set up as independent subsidiaries, such as BJEV or Chery EV. At the same time, it also includes some startups with rich experience in vehicle design, research and development, or production, such as ZD. Such enterprises have been established for a short time, and some business still needs to be outsourced.

Based on the ranking of new energy vehicle sales over a certain number of years, this article preliminarily screens out forty in the mainstream market of China's new energy passenger car enterprises, including twenty-five traditional vehicle enterprises and fifteen newly approved enterprises with pure electric vehicle production qualifications. In order to compare the differences in business models among different ownership categories, we study in depth the shareholder's structure of the forty enterprises, taking into account the versatility of resources and the consistency of strategy between parent company and subsidiary. From the perspective of the group company, we screen out other merged subsidiaries and related off-site production enterprises, and end up with thirty independent vehicle manufacturers (see Table 1), comprising twelve SOEs, thirteen PEs and five JVs. According to statistics, in 2016 the sales of new energy passenger vehicles of these 30 enterprises accounted for $99.2 \%$ of the total market, covering almost all mainstream enterprises in China. Therefore, this article selects these 30 enterprises with leading sales for analysis. 
Table 1. Sample description.

\begin{tabular}{|c|c|c|c|}
\hline Enterprise & Ownership & Market Share & New Production Qualification \\
\hline BYD & PE & $27.4 \%$ & \\
\hline BAIC & SOE & $13.66 \%$ & YES \\
\hline ZOTYE & $\mathrm{PE}$ & $10.63 \%$ & \\
\hline SAIC & SOE & $7.04 \%$ & \\
\hline DF & SOE & $6.84 \%$ & \\
\hline ZD & PE & $5.78 \%$ & YES \\
\hline JAC & SOE & $5.23 \%$ & YES \\
\hline GEELY & $\mathrm{PE}$ & $4.89 \%$ & \\
\hline CHERY & SOE & $4.85 \%$ & YES \\
\hline JMC & SOE & $4.44 \%$ & \\
\hline KANDI & PE & $2.89 \%$ & \\
\hline CHANGAN & SOE & $1.8 \%$ & \\
\hline LIFAN & $\mathrm{PE}$ & $1.24 \%$ & \\
\hline GAC & SOE & $1.04 \%$ & \\
\hline JINKANG & PE & $0.92 \%$ & YES \\
\hline DENZA & JV & $0.58 \%$ & \\
\hline FAW & SOE & - & \\
\hline BRILLIANCE & SOE & - & \\
\hline YUDO & SOE & - & YES \\
\hline HUATAI & PE & - & \\
\hline $\mathrm{HOZON}$ & PE & - & YES \\
\hline CH AUTO & PE & - & YES \\
\hline GREAT WALL & PE & - & \\
\hline SD & PE & - & YES \\
\hline WANXIANG & PE & - & YES \\
\hline GREEN WHEEL & PE & - & YES \\
\hline SOUEAST & JV & - & \\
\hline NEVS & JV & - & YES \\
\hline CHANGJIANG & JV & - & YES \\
\hline MINAN & JV & - & YES \\
\hline
\end{tabular}

\subsection{Data Collection}

In this article, financial data and information are taken from the annual reports of enterprises in 2016 and related official news websites. Business model characteristics are represented by business model elements. Taking resources into account, the article limits itself to a few main components to maintain a certain simplicity [25]. These are value (product value), customer (channel to customer), supply relation (suppliers), a model of financing its business (revenue), and certain organization resources (shareholder, human, asset, research institution, patent) [47]. In this article, product value is reflected by the average unit price of a product, i.e., the ratio of main business revenue to total sales of an enterprise. Dealers are the channel via which consumers purchase products. The $4 S$ dealer numbers reflect their market size. Supplier metrics are applied by the number of suppliers and corresponding partners. Research and development capabilities are characterized by research and development 
funding, researchers, and patents. The shareholder dimension is expressed in terms of the number of shareholders of an enterprise. Revenue comes from every company's revenue and each owner's equity [12].

\section{Results}

\subsection{Ownership Affects Business Model}

Based on the hypotheses, using analysis of variance (ANOVA), the characteristics of the three ownership categories in this article are tested. The sample is divided into three ownership groups-SOEs, PEs, and JVs. Then, we compare the differences between the components of the business models, such as product value, supply channel, operating channel, research and development capability, finance, and shareholder structure, of these three types of enterprise (see Table 2).

Table 2. Analysis of variance (ANOVA) of business models with different types of ownership.

\begin{tabular}{|c|c|c|c|c|}
\hline & & df & $\mathbf{F}$ & sig \\
\hline \multirow[t]{2}{*}{ Product } & Between Groups & 2 & 0.874 & 0.435 \\
\hline & Within Groups & 17 & & \\
\hline \multirow[t]{2}{*}{ Supplier } & Between Groups & 2 & 2.87 & 0.115 \\
\hline & Within Groups & 8 & & \\
\hline \multirow[t]{2}{*}{ Dealer } & Between Groups & 2 & 3.318 & 0.075 \\
\hline & Within Groups & 11 & & \\
\hline \multirow[t]{2}{*}{ Asset } & Between Groups & 2 & 5.809 & $0.008^{* * *}$ \\
\hline & Within Groups & 25 & & \\
\hline \multirow[t]{2}{*}{$\mathrm{R}$ and D personnel (\%) } & Between Groups & 2 & 6.258 & $0.006^{* * *}$ \\
\hline & Within Groups & 26 & & \\
\hline \multirow[t]{2}{*}{$\mathrm{R}$ and $\mathrm{D}(\%)$} & Between Groups & 2 & 0.649 & 0.532 \\
\hline & Within Groups & 23 & & \\
\hline \multirow[t]{2}{*}{ Patent } & Between Groups & 2 & 7.858 & $0.003^{* * *}$ \\
\hline & Within Groups & 23 & & \\
\hline \multirow[t]{2}{*}{ Revenue } & Between Groups & 2 & 8.731 & $0.002^{* * *}$ \\
\hline & Within Groups & 20 & & \\
\hline \multirow[t]{2}{*}{ Equity } & Between Groups & 2 & 18.007 & $0.000^{* * *}$ \\
\hline & Within Groups & 18 & & \\
\hline \multirow[t]{2}{*}{ Shareholder } & Between Groups & 2 & 1.689 & 0.204 \\
\hline & Within Groups & 27 & & \\
\hline
\end{tabular}

Products are expressed in terms of the average price. Suppliers and dealers are the number of suppliers and the number of dealers, respectively. The proportion of research and development investment, the proportion of research and development personnel, and the number of patents representing technology belong to core resources. Equity, revenue, and the number of shareholders are included in revenue structure. Due to the large order of magnitude, in order to facilitate statistical analysis, this article carries out an arcsine conversion of percentage data (ratio of research and development investment to research and development personnel), and makes a logarithmic transformation for other indicators. Variance analysis is shown in Table 2. ${ }^{* * *}$ represents significant values at $1 \%$ level.

There is a partly significant effect of ownership on business models in terms of core resources and value capture structure. Other dimensions are not obviously significant due to incomplete data. Sample size of product, suppliers, and dealers are all less than 20. The significance shows that the business models of SOEs, PEs, and JVs are linked to different types of assets. Hypothesis 5 is thus established. 
First, the impact of ownership on the product dimension is not obvious. This is due to the fact that only mass-produced EV data are available in the samples. At present, traditional vehicle enterprises sell cars that are mainly economical and low-cost models. Those enterprises still in the research and development stage, test stage or operational stage do not count. They do not exert any particularly large market effect yet. Therefore, the results show that the differences are not obvious. It is necessary to analyze the differences in the value of electric vehicles using qualitative analysis.

Second, the differences between ownership categories are not significant among suppliers, dealers, or partners either, but the gap in supplier strength will have an impact on the business model of EV enterprises. Through further comparisons, we established that there are some differences between SOEs $(P=0.042)$ and PEs $(P=0.030)$ in terms of the dealers. At present, JVs such as DENZA, SOUEAST, and NEVS, which manufacture electric vehicles, have not made breakthroughs in their commercial applications. The sales channels are monotonous. SOEs and PEs are more active in the commercial market.

Third, in terms of core resources and core technical capabilities, there are significant differences between EV enterprises with different ownerships. The enterprises' total assets accumulated through history are significant because of the influence of ownership $[\mathrm{F}(2,25)=5.809, P=0.008]$. In addition, the differences of assets between SOEs and PEs are significant $(P=0.011)$, and the differences of assets between SOEs and JVs are also significant $(P=0.006)$, but when comparing PEs and JVs, there is no significant difference $(P=0.369)$ according to the quantitative analysis. Without support from the government, the resources of PEs and JVs are both limited.

Technological capability is one of the core resources. As an important indicator of technological capabilities, the number of research and development personnel accounts for a large proportion of the total number. There are significant differences among three ownership classes $[F(2,26)=6.258$, $P=0.006]$. By comparison, the numbers of patents owned by SOEs and PEs tend to be close to each other $(P=0.112)$. Among resource-rich enterprises, BYD, GEELY, and other powerful PEs are leading the development of China's electric vehicle industry, similar to SOEs. Except for the above two indicators, the proportion of research and development investment is not significant. In fact, research and development is of great importance to every enterprise nowadays. Because the new energy vehicle industry urgently requires technological innovation and breakthroughs at this stage, all enterprises are trying their best to invest in research and development.

Finally, the revenues of SOEs, PEs, and JVs show a significant difference $[\mathrm{F}(2,20)=8.731, P=0.002]$. Besides, there is a significant difference in equity among different ownerships $[F(2,18)=18.007$, $P<0.05]$, although they have different shareholder structures, and the number of shareholders has little effect on the business model $(P=0.204)$.

\subsection{The Impact of Strategy and Resources on the Business Model}

Just like the above results for ANOVA, the core resources and value revenue structure of the business model demonstrate significant differences affected by ownership. Combining the literature review and research hypotheses, business model differences are determined by different resource capabilities and different competitive strategies which aim to establish a competitive revenue structure. The business model consists of visible strategies: we use visible resources-asset [48] and visible strategies-strategic positioning as classification standards. All thirty firms are shown in Table 3. Total assets of more than 2000 million (EUR) are seen as resource-rich; below that are defined as resource-poor. Strategic positioning is classified as with global strategy or local strategy. 
Table 3. Visible resources and strategy of samples.

\begin{tabular}{|c|c|c|}
\hline Enterprise & Strategic Positioning & Total Assets 2016 \\
\hline BYD & Global & 19,761 M€ \\
\hline BAIC & Local & 23,006 M€ \\
\hline ZOTYE & Global & $560 \mathrm{M} €$ \\
\hline SAIC & Global & $80,452 \mathrm{M} €$ \\
\hline DF & Global & 25,194 M€ \\
\hline ZD & Global & $120 \mathrm{M} €$ \\
\hline JAC & Global & $6704 \mathrm{M} €$ \\
\hline GEELY & Global & 28,161 M€ \\
\hline CHERY & Global & 10,612 M€ \\
\hline JMC & Local & $3336 \mathrm{M€}$ \\
\hline KANDI & Local & $60 \mathrm{M} €$ \\
\hline CHANGAN & Global & 14,613 M€ \\
\hline LIFAN & Global & $4002 \mathrm{M€}$ \\
\hline GAC & Global & 11,182 M€ \\
\hline JINKANG & Global & $2702 \mathrm{M} €$ \\
\hline DENZA & Local & $424 \mathrm{M} €$ \\
\hline FAW & Global & 41,927 M€ \\
\hline BRILLIANCE & Global & 19,584 M€ \\
\hline YUDO & Global & $256 \mathrm{M} €$ \\
\hline HUATAI & Global & $6343 \mathrm{M€}$ \\
\hline HOZON & Local & $158 \mathrm{M} €$ \\
\hline $\mathrm{CH}$ AUTO & Local & $275 \mathrm{M} €$ \\
\hline GREAT WALL & Global & 12,574 M€ \\
\hline SD & Global & $360 \mathrm{M} €$ \\
\hline WANXIANG & Global & $1569 \mathrm{M€}$ \\
\hline GREEN WHEEL & Global & $243 \mathrm{M} €$ \\
\hline SOUEAST & Global & $2234 \mathrm{M€}$ \\
\hline NEVS & Global & $586 \mathrm{M} €$ \\
\hline CHANGJIANG & Global & $109 \mathrm{M} €$ \\
\hline MINAN & Local & $341 \mathrm{M} €$ \\
\hline
\end{tabular}

Using these data, this article divides China's new energy vehicle enterprise into four categories according to visible resources and strategic positioning (Figure 2). The first category of enterprises (Type A) consists of eight state-owned enterprises, six powerful private enterprises and a joint venture with total assets of more than 2000 million (EUR), adopting a global strategy. The second category of enterprises (Type B) consists of two state-owned enterprises, with total assets of more than 2000 million (EUR), but adopting a local strategy. The third category of enterprises (Type C) consists of three private enterprises and two joint ventures with total assets below 2000 million (EUR), adopting a local strategy. The fourth category of enterprises (Type D) consists of one newly state-owned enterprises, six private enterprises and a joint venture with total assets below 2000 million (EUR), adopting a global strategy. In this way, a classification framework based on the characteristics of enterprise ownership, resources, and strategic positioning are coordinated and constrained. 


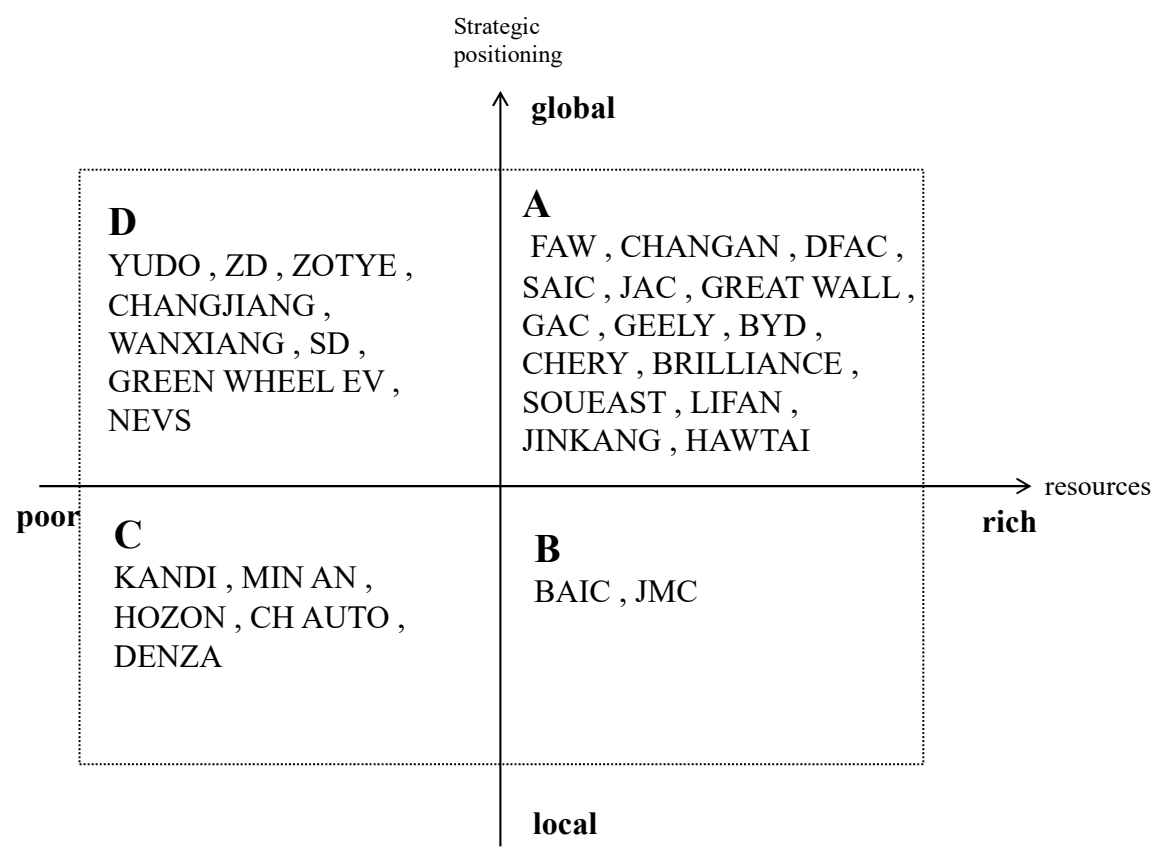

Figure 2. Classification framework of China's new energy vehicle enterprises.

Table 4 shows the general characteristics representing a business model from every enterprise block. By comparing and analyzing the indicators, which constitute a weighted average, the four types will reveal their industry history and strategy choice.

Table 4. General characteristics of enterprise archetypes.

\begin{tabular}{cccccc}
\hline & A & B & C & D & Mean \\
\hline Products value & $12,221 \mathrm{M} €$ & $9886 \mathrm{M} €$ & $15,400 \mathrm{M} €$ & $6045 \mathrm{M} €$ & $11,170 \mathrm{M} €$ \\
\hline EV sale & 19,530 & 31,799 & 6087 & 15,208 & 20,481 \\
\hline EV sale percentage & $3.32 \%$ & $4.02 \%$ & $100 \%$ & $83 \%$ & $35.25 \%$ \\
\hline Total assets & $19,070 \mathrm{M} €$ & $20,278 \mathrm{M} €$ & $252 \mathrm{M} €$ & $475 \mathrm{M} €$ & $475 \mathrm{M} €$ \\
\hline Main business revenue & $12,593 \mathrm{M} €$ & $9535 \mathrm{M} €$ & $30 \mathrm{M} €$ & $567 \mathrm{M} €$ & $9120 \mathrm{M} €$ \\
\hline Revenue & $15,369 \mathrm{M} €$ & $9728 \mathrm{M} €$ & $30 \mathrm{M} €$ & $567 \mathrm{M} €$ & $10,947 \mathrm{M}$ \\
\hline Equity & $5939 \mathrm{M} €$ & $4798 \mathrm{M} €$ & $63 \mathrm{M} €$ & $313 \mathrm{M} €$ & $4467 \mathrm{M} €$ \\
\hline Suppliers & 366 & 265 & - & - & 357 \\
\hline Deals & 532 & 193 & 8 & 1322 & 503 \\
\hline Employee & 67,184 & 21,014 & 653 & 3113 & 44,364 \\
\hline R and D personnel & 8575 & 3.605 & - & 595 & 6582 \\
\hline R and D personnel & $13.76 \%$ & $16.50 \%$ & - & $11.64 \%$ & $15.42 \%$ \\
\hline percentage & $422 \mathrm{M} €$ & $322 \mathrm{M} €$ & $12 \mathrm{M} €$ & $23 \mathrm{M} €$ & $332 \mathrm{M} €$ \\
\hline R and D & $3.34 \%$ & $4.84 \%$ & $94.6 \%$ & $9.45 \%$ & $8.97 \%$ \\
\hline R and D percentage & 6527 & 4711 & 70 & 512 & 3876 \\
\hline Patents & 4 & 1 & 5 & 4 & 4 \\
\hline Numbers of shareholders & & & & \\
\hline
\end{tabular}

Shareholders with more than 10 people are calculated with 10 people. 
(1) Business model characteristics of Type A

Type A enterprises have rich resources that target the global market. In terms of output, the sales of Type A contribute $3.32 \%$. Compared to gasoline vehicles, new energy vehicles are still not dominant. The sales volume of new energy vehicles and the average unit price of products are the same as the averages of the industry. The product positioning of Type A is mainly economy/low-cost. The main business revenue is higher than the industry average, developing steadily. The number of suppliers in Type A is significantly higher than in the other types, with a strong group of partners, which reflects its good resource base. The number of dealers is equal to the industry average. In terms of research capacity, the number of employees is large, but the number of researchers is at the average level. The research and development investment is below the average of $8.97 \%$, which is insufficient. Although patents are twice the industry average, the per capita patent ratio is not high. At the same time, business revenue and equity are above average.

(2) Business model characteristics of Type B

Type B firms have rich resources that target the local market. The products they launched are also economy models, which match the development needs of the local market. For example, BAIC and JMC have a series of ecological chain systems, such as leasing, public transportation, and car-sharing in the local market. These enterprises have a variety of product-promotion methods and occupy a large market share. The number of suppliers and dealers is relatively small compared to Type A. This may be due to the limitation of regional development. Overall, the research capacity of this cluster is relatively higher, with a proportion of $16.50 \%$. The ratio of research and development to revenue is $4.84 \%$, which is higher than Type A. The shareholder structure of solely state-owned enterprises is simple: there is only one owner. Both enterprises are dominated by the local State-owned Assets Supervision and Administration Commission (SASAC). Main business revenue and equity are lower than Type A, but they are equal to the industry average.

(3) Business model characteristics of Type C

Type $C$ have relatively poor resources that target the local market. Most enterprises in Type $C$ are small and medium-sized enterprises that are newly qualified in the EV industry. As emerging enterprises, they are still in their infancy. Products are not mass produced, so this cluster has fewer models. However, the proportion of new energy products is $100 \%$. The enterprises DENZA, KANDI, HOZON, MIN AN, and CH AUTO only produce and sell electric vehicles. Except for KANDI's urban micro-bus positioning, the rest aim at luxury models. For example, $\mathrm{CH}$ AUTO aims to produce luxury electric sports vehicles. Further, DENZA's positioning is high end and, apart from traditional $4 S$ shop sales, it uses its parent enterprises' sales channels, BYD and Daimler. In terms of suppliers, relying on its parent company, DENZA has gained support from BYD's battery technology and Daimler's advanced design. Compared to $A$ and $B$, the number of shareholders in Type $C$ is higher. The startup enterprises have invested heavily in research and development while sales are limited so the research and development investment ratio is $94.6 \%$ of total revenue.

(4) Business model characteristics of Type D

Type D have poor resources that target the global market. The average product value in Type D is far lower than the average price. However, the value propositions of Type $\mathrm{D}$ are diversified. The enterprises ZD and ZOTYE are more inclined to low-end electric vehicles, whereas NEVS aims at the market segment of mid-size commercial cars. Type D are active in sales, logistics, rental, public transportation, and leasing. The number of dealers is the largest of the four types. The number of research and development personnel is huge; however, the research and development itself seems slightly insufficient. It is still higher than the average level of A and B. From the perspective of shareholder structure, the majority of shareholders of PEs are natural person shareholders and related investment institutions. Total assets, revenue, and equity are better than Type C.

Above are descriptions that illustrate the differences in business model characteristics defined by strategy and resources. It is shown that hypotheses 3 and 4 are valid. The following sections using the classification framework will analyze why ownership determines strategy and resources. 


\subsection{Ownership Determines Resources and Strategy}

Based on the classification framework of China's NEV enterprises, invisible resources and strategy contribute to their business model. This section further explores the reasons for business model differentiation, considering the historical background of enterprise resources and the enterprise's competitive strategy as part of a discussion about strategic choice.

\subsubsection{The Source of Resources with the Business Model}

Given the unique history of every company, the amount and quality of assets are dependent on historical resources. Among all firms, there are three kinds of resource acquisition forms. Firstly, existing traditional vehicle manufacturing enterprises have rich human resources, technology, and equipment for accumulating further resources. Secondly, joint venture provide opportunities to acquire substantial resources in the form of capital, social networks, and auto-manufacturing experience from partners. Thirdly, emerging enterprises acquire resources from shareholders and the market, but often with slightly weaker results.

For expressing the effect of historic resources, this article divides the approach of resource acquisition into "only" and "both". "Only" means enterprises that only produce new energy vehicles. "Both" refers to enterprises that rely on strong resources and produce both new energy vehicles and traditional vehicles. Then, the different enterprises are categorized into groups as shown in Table 5.

Table 5. Source of resources for different enterprises.

\begin{tabular}{ccc}
\hline & Only & Both \\
\hline Rich & - & SOEA, SOEB, PEA, JVA \\
\hline Poor & PEC, JVC, SOED, JVD & PED \\
\hline
\end{tabular}

According to the statistics, the enterprises that only produce electric vehicles have not accumulated rich asset yet. Enterprises that both produce traditional vehicles and new energy vehicles are still the mainstay. Resource-rich enterprises include SOEs in Type A and B, and PEs and JVs in Type A. These enterprises have the necessary production resources, such as factories, equipment, talent, and technology, and also have invisible assets in the form of sales chains, product markets, brand reputations etc. Therefore, these enterprises have played an important role in opening up the field of new energy vehicles.

In terms of ownership, we can compare the resources from an input-output perspective. According to the RBV theory, enterprises with resource advantages will have better market performance. If it is assumed that the resource investment of new energy vehicle producers is linked to their sales volumes, computing the input-output ratio of enterprises in different ownership categories will help us understand the important relationship between resource acquisition and enterprise ownership.

Table 6 shows the proportion of new energy vehicle investment to total sales at the enterprise level and represents the relative value of investment. We assume that how many EVs a company sells meaning that how much resources it invests. Therefore, the proportion is used to represent how much resources an enterprise invests in a same group. We compare the effect of different ownership on resources in each group. The major contributors of SOEA (SOEs in Type A) and PEA (PEs in Type A) invested $1.86 \%$ and $9.60 \%$, respectively. 
Table 6. Proportion of new energy vehicle investment to total sales.

\begin{tabular}{ccccc}
\hline EV\% & A & B & C & D \\
\hline SOE & $1.86 \%$ & $4.02 \%$ & & $100 \%$ \\
\hline PE & $9.60 \%$ & & $100 \%$ & $24.16 \%$ \\
\hline JV & - & & $100 \%$ & $100 \%$
\end{tabular}

$\mathrm{EV} \%$ represents the proportion of electric vehicles to the enterprise's total sales of all kinds of cars.

In Table 7, which reflects the relative value of total output that is market shares at the industry level, it can be seen that sales of SOEA accounted for $13.75 \%$ and PEA accounted for $34.35 \%$ of total industry sales. According to the input-output results, the ratio of SOEA is 7.39, whereas the ratio of PEA is 3.58. That means that SOEA spent relatively less resources to achieve stronger market sales. Therefore, SOEs have more resources than PEs. Compared to JVs and PEs, JVC (joint ventures in Type C) invested $100 \%$ resources, with a market share of $1.78 \%$. PEC (private enterprises in Type C) also invested $100 \%$ resources but gained a market share of $8.89 \%$. The ratio of PEC is 8.89 , whereas the ratio of JVC is 1.78. Thus, among China's new energy vehicle enterprises, PEs have more resources than JVs. SOEs have more resources than PEs. Most SOEs have been able to obtain more and better resources. The externalities of SOEs are embodied in the system which has the greatest resource priority [13].

Table 7. Sales of new energy vehicles and shares of total EV sales.

\begin{tabular}{cccccccccc}
\hline EV & A & A(\%) & B & B(\%) & C & C(\%) & D & D(\%) & Total \\
\hline SOE & 15,683 & 13.75 & 31,799 & 27.89 & & & - & & 47,482 \\
\hline PE & 39,164 & 34.35 & & & 10,148 & 8.90 & 15,208 & 13.34 & 64,520 \\
\hline JV & - & & & & 2025 & 1.78 & - & 15,208 & 2025 \\
\hline Total & 54,847 & & 31,799 & & 12,173 & & 114,027 \\
\hline
\end{tabular}

$\mathrm{A}(\%)$ represents the market share of SOEA, computed through the sales of SOEA divided by the total sales of new energy vehicles. $\mathrm{B}(\%), \mathrm{C}(\%), \mathrm{D}(\%)$ are the same as $\mathrm{A}(\%)$, albeit corresponding to different types.

Although Type A and Type B are both resource rich, the ratio of SOEA is higher than SOEB. According to input-output results, the ratio of SOEA is 7.39, whereas the ratio of SOEB is 6.93. The remaining small difference comes from corporate strategic differences. Resource priorities trigger negative externalities, which are lack of entrepreneurship and fairness [49]; these will further affect strategic selection and market positioning, which are top priorities in the design of business model.

In summary, the first hypothesis that the business model is based on resources is proved. Ownership provides resource priorities for some enterprises. We have also discovered that enterprise resources are the foundation of enterprise strategy.

\subsubsection{Competitive Strategies with the Business Model}

The new energy vehicle industry has gradually shifted from policy-pull to market-push. The strategy of enterprise on the one side depends on the outside market; on the other side, it is decided by shareholders. Porter has put forward three major competition strategies: cost-leadership strategies, differentiation strategies, and centralized strategies [50]. In this article, enterprises with high-profit margins are defined as cost-leadership enterprises. Enterprises that adopt differentiated strategies and specialized strategies are classified as other strategic choices. Based on the above comparative analysis, as shown in Table 8, and according to the visible strategy of enterprises in the classification framework, the invisible competitive strategy is analyzed. 
Table 8. Competitive strategy of different enterprises.

\begin{tabular}{ccc}
\hline & Cost-Leadership & Others \\
\hline Global & SOEA, JVA, PED & PEA, SOED, JVD \\
\hline Local & SOEB, PEC & JVC \\
\hline
\end{tabular}

Overall, most enterprises choose cost-leadership competitive strategies, and a few enterprises choose other strategies. SOEs (A and B) with resource advantages have chosen cost-leadership strategies. Only one startup enterprise, YUNDO Vehicle, adopts a focused strategy on SUV products. SOEs of Type A have a vast global market, large-scale production, relatively mature technology, and abundant resources to maintain their long-term low-cost advantages.

As far as PEs are concerned, resource-rich PEs have diversified competition strategies, whereas PEs with weak resources are still dominated by cost-leadership strategies. PEs of Type $C$ have a low cost, but low-cost products that are suitable for local development. Due to the lower product cost, the enterprise has a higher market share in the local market, resisting the entry of other competitors within the controllable range and improving the bargaining ability between suppliers and dealers. Thus, they can obtain a regional cost advantage.

Differentiated strategies in a joint venture are obvious. Only SOUEAST, a joint venture with stronger resources, has chosen a cost-leadership strategy, whereas emerging JVs with more limited resources regard luxury electric vehicles as their main products, such as NEVS and DENZA. Joint ventures often rely on the good reputation of the cooperating enterprises and foreign advanced technologies to join the rank of cost leaders.

According to the reasons for the choice of strategic positioning, competitive strategy leads the business model. We have confirmed the second hypothesis: the business model is driven by different strategic goals.

\subsection{Business Model of Different Ownership}

Business model differences are based on resources and linked to competitive strategy. The reasons for the differences between companies are mainly influenced by the company's strategy and resources. This part will summarize the pattern of business models used by firms under different ownerships (see Figure 3).

\begin{tabular}{|c|c|c|c|c|c|c|c|c|}
\hline \multirow{2}{*}{$\begin{array}{c}\text { Business } \\
\text { model } \\
\text { characteristics }\end{array}$} & \multicolumn{2}{|c|}{ Strategy Positioning } & \multicolumn{2}{|c|}{ Competitive Strategy } & \multicolumn{2}{|c|}{ Resource } & \multicolumn{2}{|c|}{ History } \\
\hline & Local & Global & Cost & Others & Poor & Rich & Only & Both \\
\hline SOE & & & & & & & & \\
\hline PE & & & & & & & & \\
\hline $\mathbf{J V}$ & & & & & & & & \\
\hline
\end{tabular}

Figure 3. Characteristics of a business model under different types of ownership.

First, China's state-owned enterprises are the mainstay of China's new energy vehicle industry. Most SOEs are traditional vehicle-manufacturing enterprises. They have rich resources and adopt cost-leading competitive strategies to produce economical new energy vehicles. They occupy a low-cost, first-mover advantage in China and rely on continuous innovation to maintain their positions. It is 
difficult for other competitors to break the monopoly of SOEs in the low-end market. Guided by this strategy, most enterprises implement global strategic positioning.

Second, China's private enterprises have made positive contributions to the sustainable development of EVs. Few PEs have developed from traditional vehicles to EVs, and hold stronger resources. The development of PEs is not balanced. Private enterprises design more aggressive business models, such as developing new consumer groups and producing more popular low-speed electric vehicles. However, in order to avoid competing with SOEs, most PEs have chosen other competitive strategies than cost-leadership. They actively expand in the international market with the guidance of other strategies.

Third, China's joint venture will be an integral part of the future new energy vehicle field. The resources owned by the joint venture are still limited, despite the fact that JVs have drawn resources from both domestic and foreign sources. With traditional vehicles gradually disappearing, the business models of JVs will in the future accommodate more enterprises that want to enter the new energy vehicle field.

In summary, Figure 3 in further supports the hypothesis that enterprise ownership affects enterprises' business models.

\subsection{Dynamic Transition of Business Model}

Business models allow us to understand the internal coherence of strategy in a company and to characterize their resources. We have obtained the business model types represented by resource history, competitive strategy, and ownership, as shown in Figure 4. This representation helps to explain the links between ownership, business model, strategy, and resources. At the same time, it can be seen that, under the influence of various factors, the business model may shift dynamically.

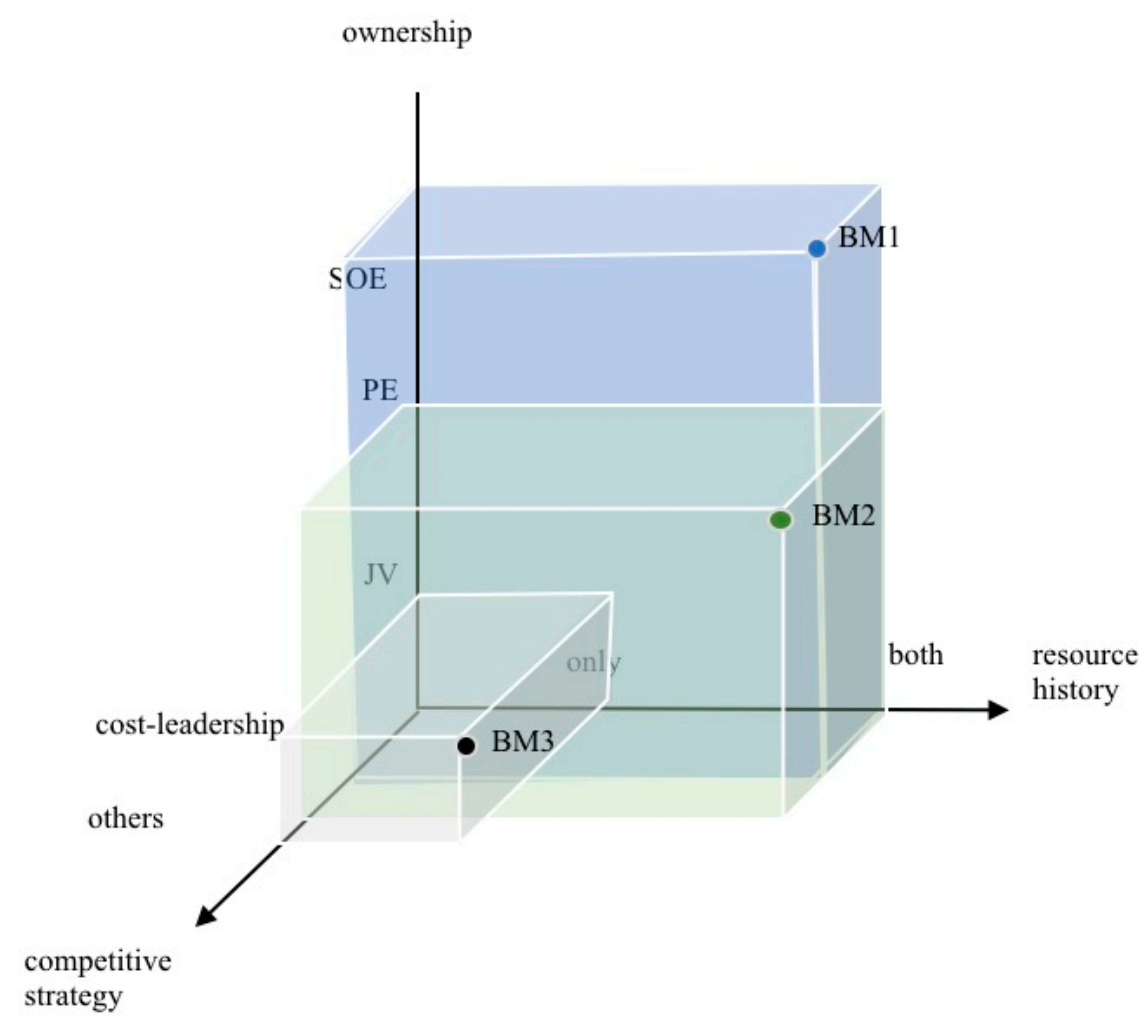

Figure 4. Dynamic transition of business model types.

As shown in Figure 4, there are 3 types of business model formed by the collocation of different strategies and resources based on SOEs, PEs, and JVs. Strategies refer to cost-leadership and other strategies that differentiate the firm from industry/cost leaders. Resources refer to the historical 
resources of the enterprise, whether they produce traditional vehicles or new energy vehicles (or both). The closer to the base point, the more unstable the business model is. The types of business model will change with changes in strategies and resources.

For the SOEs, BM1 will gradually move toward other strategies, such as differentiation strategy and centralization strategy. When the strategy is changed, the business model will also change. For example, in the early stages, the products made by SOEs were inexpensive and occupied the market with cost-leadership strategies. With the increase of consumer demand, the low-quality problem is hidden by the enterprise's market expansion. Therefore, the incumbents choose to develop new high-end brands or choose to cooperate with other high-end brands to get rid of the impediments of low brand value. One enterprise undergoing such a change is BAIC, which focuses on the local market. It began to invest in the global market from 2014 and officially took a 25\% stake in the American firm Atieva. It is trying to push its products from the local market to the global market, which means that its business model will also be reformed in the future.

For the PEs, strategic positioning has a greater impact on the business model. Why can they produce traditional vehicles but cannot accumulate more resources to support their new energy vehicles? Some PEs benefit from their technology-based differentiation strategies. Those with global positioning have more dealers, stronger research and development capabilities, and stronger suppliers, On the basis of these strategies, they vigorously expand overseas markets, establish overseas research and development centers, and merge with foreign automobile enterprises. However, PEs with a local strategy have smaller research and development staff and poorer revenues despite relying on the historical foundations of the owning enterprise. Maybe global strategic positioning improves resource acquisition. The enterprise BM2 should be analyzed according to specific business conditions.

Of the JVs, BM3 may not evolve to "both" resources. Due to a lack of sufficient resources, JVs face difficulties at the development stage [51], and they are subject to competition from the SOE market and PE products. As traditional vehicles gradually disappear, and the double-credit policy is launched, the difference in resources will gradually diminish and the advantages of traditional vehicles will start to fade. Other elements such as technology and partnerships will dominate future business models.

\section{Discussion}

This article demonstrates the influence of ownership on business models. However, with the rapid development of the new energy vehicle industry, there are some topics deserving a brief discussion.

\subsection{State-Owned Enterprises Adapt to Business Model Transition by Adjusting Sociotechnical System}

Loorbach and Wijsman studied the co-evolution process of social sustainable transition and enterprise transition, and put forward that enterprises restructured the existing business model according to the changes of environment and social-technology [52]. This suggests that the interaction between social elements and technology will promote business model transition. As time goes by, new energy vehicles are moving towards a more motorized, intelligent, networked, and shared direction. Technology as the basis of industry innovation, has an impact on the resource structure. Technology will break the existing balance of social-technology systems, and change the resources needed by new energy vehicles as well. The transition management including four different activities can be defined within the contexts of actors' behavior, and social transitions: strategic, tactical, operative, and reflexive [53]. As an important sociotechnical system, state-owned enterprises constantly adjust operational activities according to the strategic guidance of the upper political level. Moreover, these enterprises adjust the sociotechnical system by introducing new laws and regulations [54], so as to reach a technological transition and provide a new balance for the sustainable transition of development or innovation processes of the new energy vehicles industry. 


\subsection{Actors with New Ownership will Change the Existing Business Model}

The Chinese government clearly relaxed the restrictions on the number of joint ventures established by foreign investors to produce pure electric vehicle products in 2017. Tesla became the first wholly foreign-owned new energy vehicle enterprise in China. Compared with foreign-funded enterprises, China's state-owned enterprises and private enterprises have apparent resource advantages, such as the first-mover advantage, local advantage, innovation advantage, production and marketing advantage, some of which will be threatened by foreign entry The new foreign entrants also pose challenges related to technology, brands, operations and management, talent acquisition and capital. With the entry of foreign-funded enterprises, the competition in China's vehicle market has become more intense, affecting the entire industry.

\subsection{How Incumbent Enterprise Maintain the Competitive Advantages}

With increasing industry sales, more and more enterprises enter into the field of new energy vehicles. Market competition is becoming increasingly fierce. Production subsidies are gradually phased out, and the independent new energy vehicle enterprises that originally enjoyed first-mover advantage are challenged by the latecomers. This article has analyzed the development trajectory of four types of enterprises through the comparison of strategy and resources. Incumbent enterprises with first-mover advantages are carrying out incremental innovation in order to maintain marginal profits, however, incremental innovation may lead to institutional and technological path dependence. Unlike incumbents, latecomers are less constrained by path dependence, because their flexibility allows them to design more radical business models at their early stages. It is significant to continue to pay attention to the business models of China's new energy vehicle producers, distinguishing between incumbents and latecomers.

\section{Conclusions}

The business model is tool for organizations to use resources to create, deliver and capture value for their partners and consumers and thus realize their strategic goals. Based on the resource-based view theory, this article analyzes the impact of ownership on business models in China's new energy vehicle enterprises and obtains the following results.

The ownership of China's new energy vehicle enterprises has an impact on the business model. By collecting data from 30 new energy vehicle enterprises, using ANOVA to analyze elements of the business models, this article shows that the business model elements differ between ownership categories in resources (asset, patent, $\mathrm{R}$ and $\mathrm{D}$ personnel) and value capture (revenue and equity).

The business model is the result of matching the competitive strategy with historical resources. Based on differences in business model dimensions, this article constructs a classification framework of new energy vehicle enterprises, which takes the resources as the $X$-axis and the strategic positioning as the Y-axis. Descriptive statistics are presented for different enterprise classifications, showing that elements of the business model are different because combinations of different strategies and resources have an impact on the business model. It provides a basis for further exploring the reasons behind differences in business models.

By the method of generalization and summarization, all enterprises are included in an analytical framework focusing on resources, including intangible resources, so as to get a distribution map of resource acquisition under different ownerships. Using a similar qualitative method, a distribution map for strategic positioning is determined. This shows that ownership plays a decisive role in strategic choice and resource acquisition.

Based on the study of the relationship between ownership, resources, strategy, and business models, this article identifies a stylized leading business model for state-owned enterprises, private enterprises, and joint ventures, respectively. Most state-owned enterprises employ a business model based on cost leadership and production of both EVs and traditional vehicles. The private enterprises' 
business model favors product differentiation and production of both EVS and traditional vehicles, whereas the main joint ventures have selected a strategy based on differentiation and full focus on EVs. The difference between state-owned enterprises and private enterprises arises from the fact that enterprises choose different competitive strategies based on ownership (decisions of shareholders) and long-term history. The difference between private enterprises and joint ventures lies in the historical background. Private enterprises usually have experience in traditional vehicles, while JVs are newcomers without car manufacturing experience in China (but often with the necessary competence and technology through foreign partners).

The dynamic migration of business models of China's new energy vehicle enterprises will be interesting to follow. The business model of China's new energy vehicle enterprises is not static and will change over time. The business model of state-owned enterprises are likely to gradually move from cost leadership in the economy segment toward other strategies, such as the differentiation strategy or centralization strategy. The business model of joint ventures private enterprises are also likely to change, and the overall market environment changes as a result of technological development and strategic transitions in the SOE sector. The likely direction is more differentiation and stronger focus on specific market segments. However, resource acquisition will remain a challenge both for JVs and private enterprises, and a subject for further in-depth study.

Author Contributions: Conceptualization, L.Z. and A.K.; methodology, A.K.; software, L.Z.; validation, L.Z. and A.K.; formal analysis, L.Z.; investigation, L.Z.; resources, Y.L. and A.K.; data curation, L.Z.; writing-original draft preparation, L.Z.; writing-review and editing, Y.L. and A.K.; visualization, A.K.; supervision, Y.L. and A.K.; project administration, Y.L.; funding acquisition, Y.L.

Funding: This research was funded by the National Social Science Fund of China, grant number 16AGL004.

Conflicts of Interest: The authors declare no conflict of interest.

\section{References}

1. IEA. Global EV Outlook 2016 - Beyond one Million Electric Cars; OECD/IEA: Paris, France, 2016; pp. 7-8.

2. Gong, T. 2016 Oil and Gas Industry Development Report at Home and Abroad. Nat. Gas Ind. 2017, 1, 30.

3. IPCC. Summary for policymakers. In Climate Change 2014: Mitigation of Climate Change; Contribution of Working Group III to the Fifth Assessment Report of the Intergovernmental Panel on Climate Change; Edenhofer, O., Pichs-Madruga, R., Sokona, Y., Agrawala, S., Bashmakov, L., Blanco, G., Broome, J., Bruckner, T., Brunner, S., Bustamante, M., et al., Eds.; Cambridge University Press: Cambridge, UK, 2014; pp. 9-19.

4. China's Auto Industry Production and Sales Statistics and Analysis of Retained Growth Rate in 2016. Available online: http://www.chyxx.com/industry/201703/504459.html (accessed on 25 April 2018).

5. Boden, T.A.; Marland, G.; Andres, R.J. National $\mathrm{CO}_{2}$ Emissions from Fossil-Fuel Burning, Cement Manufacture, and Gas Flaring; Carbon Dioxide Information Analysis Center, Oak Ridge National Laboratory, U.S. Department of Energy: Washington, DC, USA, 2017; pp. 1751-2014.

6. China Surpasses the United States to Become the World's Largest Electric Vehicle Sales Market. Available online: http://www.china-nengyuan.com/news/99245.html (accessed on 30 November 2017).

7. China Vehicle Association: 2017 Sales of New Energy Vehicles 777,000, an Increase of 53.3\%. Available online: http://news.cnev.cn/info_105418.html (accessed on 1 March 2018).

8. Zhang, L.; Liu, Y.; Kokko, A. Evolution path of business model in China's new energy vehicle industry: Policy impact and technology drive. Presented at the MIT Applied Energy Symposium, Boston, MA, USA, 22-24 May 2019.

9. Boulton, R.E.S.; Libert, B.D.; Samek, S.M. A business model for the new economy. J. Bus. Strategy 2000, 21, 29-35. [CrossRef]

10. Prahalad, C.K.; Hamel, G. The core competence of the corporation. Harv. Bus. Rev. 1990, 68, 79-91.

11. Barney, J. Firm resources and sustained competitive advantage. J. Manag. 1991, 17, 99-120. [CrossRef]

12. Korsaa, C.R.; Røge Jensen, L. Integrating Business Models and Strategy for Sustained Competitive Advantage; Copenhagen Business School: Copenhagen, Denmark, 2010.

13. Lu, X.; Cai, J.; Wang, L. Exploration of the external impact of state-owned enterprises-empirical analysis based on the comparison between SOEs and PEs. Mark. Mod. 2013, 26, 54-56. 
14. Szamosszegi, A.; Kyle, C. An analysis of State-Owned Enterprises and State Capitalism in China; Capital Trade, In enterprised for US-China Economic and Security Review Commission: Washington, DC, USA, 2011; pp. 4-7.

15. Barquet, A.P.; Seidel, J.; Seliger, G.; Kohl, H. Sustainability factors for PSS business models. Procedia CIRP 2016, 47, 436-441. [CrossRef]

16. Jones, G.M. Educators, electrons, and business models: A problem in synthesis. Account. Rev. 1960, 35, 619-626.

17. Konczal, E.F. Models are for managers, not mathematicians. J. Syst. Manag. 1975, 26, 12-15.

18. Eden, C.; Ackermann, F. Mapping distinctive competencies: A systemic approach. J. Oper. Res. Soc. 2000, 51, 12-20. [CrossRef]

19. Chesbrough, H.; Rosenbloom, R.S. The role of the business model in capturing value from innovation: Evidence from Xerox Corporation's technology spin-off enterprises. Ind. Enterp. Chang. 2002, 11, 529-555. [CrossRef]

20. Richardson, J. The business model: An integrative framework for strategy execution. Strateg. Chang. 2008, 17, 133-144. [CrossRef]

21. Pejvak, O.; Rana, M. Circular business model challenges and lessons learned-An industrial perspective. Sustainability 2018, 10, 739-758.

22. Wirtz BW Schilke, O.; Ullrich, S. Strategic development of business models: Implications of the Web 2.0 for creating value on the internet. Long Range Plan. 2010, 43, 272-290. [CrossRef]

23. Afuah, A. Business Models: A Strategic Management Approach; McGraw-Hill/Irwin: Boston, MA, USA, 2004; pp. 2-13.

24. Demil, B.; Lecocq, X. Business model evolution: In search of dynamic consistency. Long Range Plan. 2010, 43, 227-246. [CrossRef]

25. Hasoneh, A. The Role of Knowledge Management in the Healthcare Sector. Int. J. Adv. Res. 2013, 1, 436-442.

26. Mangematin, V.; Lemarié, S.; Boissin, J.P.; Catherine, D.; Corolleur, F.; Coronini, R.; Trommetter, M. Development of SMEs and heterogeneity of trajectories: The case of biotechnology in France. Res. Policy 2003, 32, 621-638. [CrossRef]

27. Teece, D.J. Business models, business strategy and innovation. Long Range Plan. 2010, 43, 172-194. [CrossRef]

28. Wirtz, B.W.; Pistoia, A.; Ullrich, S.; Göttel, V. Business models: Origin, development and future research perspectives. Long Range Plan. 2016, 49, 36-54. [CrossRef]

29. Osterwalder, A.; Pigneur, Y. Business Model Generation; Osterwalder \& Pigneur: Lausanne, Switzerland, 2010.

30. Magretta, J. Why business models matter. Harvard Bus. Rev. 2002, 80, 86-92.

31. Bocken, N.M.P.; de Pauw, I.; Bakker, C.; van der Grinten, B. Product design and business model strategies for a circular economy. J. Ind. Prod. Eng. 2016, 33, 308-320. [CrossRef]

32. De Winter, J. Circular Business models: An Opportunity to Generate New Value, Recover Value and Mitigate Risk Associated with Pressure on Raw Material Availability and Price Volatility. Master's Thesis, Faculty of Geosciences, Utrecht University, Utrecht, The Netherlands, 2014.

33. Pfeffer, J.; Salancik, G.R. The External Control of Organizations: A Resource Dependence Perspective. Soc. Sci. Electron. Publ. 2003, 23, 123-133.

34. Garnsey, E.; Leong, Y.Y. Combining Resource-Based and Evolutionary Theory to Explain the Genesis of Bio-networks. Ind. Innov. 2008, 15, 669-686. [CrossRef]

35. Schweizer, L. Concept and evolution of business models. J. Gen. Manag. 2005, 31, 37-56. [CrossRef]

36. Johnson, G.; Scholes, K.; Whittington, R. Strategic Capability. In Exploring Enterprise Strategy: Text E Cases, 7th ed.; Pearson Education: London, UK, 2005; pp. 117-118.

37. Bu, Y.; Yao, C. Analysis of the relationship between business model and sustainable competitive advantage. Financ. Econ. Issues 2011, 11, 126-130.

38. McEvily, S.K.; Das, S.; McCabe, K. Avoiding competence substitution through knowledge sharing. Acad. Manag. Rev. 2000, 25, 294-311. [CrossRef]

39. Grant, R.M. Knowledge and organization. In Managing Industrial Knowledge: Creation, Transfer and Utilization; Sage: London, UK, 2001; Volume 145, p. 169.

40. Casadesus-Masanell, R.; Ricart, J.E. From strategy to business models and onto tactics. Long Range Plan. 2010, 43, 195-215. [CrossRef]

41. Amit, R.; Zott, C. Value creation in e-business. Strateg. Manag. J. 2001, 22, 493-520. [CrossRef] 
42. Rajala, R.; Westerlund, M. Business Models: A New Perspective on Knowledge-Intensive Services in the Software Industry. BLED 2005 Proceedings. 2005. Available online: https://aisel.aisnet.org/cgi/viewcontent. cgi? article $=1060 \&$ context $=$ bled2005 (accessed on 2 June 2019).

43. Tikkanen, H.; Lamberg, J.A.; Parvinen, P.; Kallunki, J.P. Managerial cognition, action and the business model of the firm. Manag. Decis. 2005, 43, 789-809. [CrossRef]

44. Dahan, N.M.; Doh, J.P.; Oetzel, J.; Yaziji, M. Enterprise-NGO collaboration: Co-creating new business models for developing markets. Long Range Plan. 2010, 43, 326-342. [CrossRef]

45. Porter, M.E. Clusters and the New Economics of Competition; Harvard Business Review: Boston, MA, USA, 1998; pp. 77-90.

46. 2017 Announcement of Credits for Chinese New Energy Vehicles Passenger Car Enterprises. Available online: http://www.miit.gov.cn/n1146295/n1652858/n1653100/n3767755/c6124752/content.html (accessed on 1 May 2018).

47. Teece, D.J.; Rumelt, R.; Dosi, G.; Winter, S. Understanding corporate coherence: Theory and evidence. J. Econ. Behav. Organ. 1994, 23, 1-30. [CrossRef]

48. Andriessen, D. IC valuation and measurement: Classifying the state of the art. J. Intellect. Cap. 2004, 5, 230-242. [CrossRef]

49. Zhang, W. Externality of State-owned Enterprises. Mil. Ind. Cult. 2013, 1, 50-51.

50. Porter, M.E.; Goold, M.; Luchs, K. From competitive advantage to enterprise strategy. In Managing the Multibusiness Company: Strategic Issues for Diversified Groups; Cengage Learning EMEA: Hampshire, UK, 1996; Volume 285, pp. 285-314.

51. Sosna, M.; Trevinyo-Rodríguez, R.N.; Velamuri, S.R. Business model innovation through trial-and-error learning: The Naturhouse case. Long Range Plan. 2010, 43, 383-407. [CrossRef]

52. Loorbach, D.; Wijsman, K. Business transition management: Exploring a new role for business in sustainability transitions. J. Clean. Prod. 2013, 45, 20-28. [CrossRef]

53. Loorbach, D. Transition Management for Sustainable Development: A Prescriptive, Complexity-Based Governance Framework. Governance 2010, 23, 161-183. [CrossRef]

54. Fogarassy, C.; Nguyen, H.H.; Oláh, J.; Popp, J. Transition management applications to accelerate sustainable food consumption—comparative analysis between Switzerland and Hungary. J. Int. Stud. 2018, 11, 31-43. [CrossRef]

(C) 2019 by the authors. Licensee MDPI, Basel, Switzerland. This article is an open access article distributed under the terms and conditions of the Creative Commons Attribution (CC BY) license (http://creativecommons.org/licenses/by/4.0/). 